\title{
Physical state of schools in Ottoman State in the early 20th century
}

\begin{tabular}{|c|c|}
\hline & Tecmettin Erbakan University, Konya, Turkey \\
\hline Article history & \multirow{6}{*}{$\begin{array}{l}\text { The purpose of this study is to investigate physical condition of schools } \\
\text { past and today in Turkey. We have selected some schools, which was } \\
\text { located in documents. We have give information about this schools' } \\
\text { physical condition. The physical states of schools are one of the necessary } \\
\text { conditions for proper education to be effectively realized. That physical } \\
\text { structures can be better in conditions depends on the economic conditions } \\
\text { or rate of budget allocated to schools. The higher this rate, the more will } \\
\text { be its reflections on education. The number of classrooms in the schools } \\
\text { will affect the number of students in the classroom, especially the order } \\
\text { and management of classroom, and the efficiency of the course. In the } \\
\text { historical process, the determinations regarding the physical structure of } \\
\text { schools are recognized through the documents recorded during the } \\
\text { supervision of schools. In this study, the information and documents } \\
\text { examined the physical states of the primary and secondary schools } \\
\text { providing education in Ottoman State. Thus, the developments from the } \\
\text { history to the present days will be provided to be better understood. On } \\
\text { the other hand, the period the last years of Ottoman State. It was observed } \\
\text { that, physical facilities of schools were not enough in the past. But good } \\
\text { faith efforts were made. Presently, review issues of the past were taken } \\
\text { into consideration. This situation indicates the educational approach in } \\
\text { the history. This study shows urban education facilities in past. }\end{array}$} \\
\hline Rec & \\
\hline & \\
\hline & \\
\hline y w & \\
\hline & \\
\hline
\end{tabular}

\section{Introduction}

Schools are not just places where scientific knowledge is given; also culture, art, education institutions are given in subjects such as politics. A school is a part of the society. School and community are mutual. The main purpose of school education is to ensure the development of the students mentally, physically and morally. The school is an institution in which social events are made and also an information slot. Friendship, sharing emotions such as joy and sorrow develop as result of the relationship among school friends (mebk12.meb.gov.tr). The school is one of the most important aspects of formal education.

Three main elements are needed to ensure efficiency in schools. These include issues are, human resources, related to physical facilities and administration. It must be in harmony with each other. When the school has better physical facilities, adequate facilities, equipment and vehicle; will be more productive. Physical structure at the school including two main topics which are indoor and outside being discussed. School buildings has classes, test room, a museum room, reading room and so on are indoor. Outside the building schools has implementation gardens, sports fields, a playground, a traffic and meteorology corners(Başar,

\footnotetext{
* Correspondence: staser@konya.edu.tr
} 
A significant portion of the time students pass in the school or in the class. Classroom environment is such a potent determinant of student outcomes. Classroom environments is naturally valuable goal of schooling(Fraser,2012;1,2). School climate include that, physical environment of the classroom, social system in the classroom, expectations about teacher behavior and student outcomes. İn this way student motivation could be better (Creemers, 1999; 31,32).

Another item that school laboratory. Rubin and Tamir says for laboratory "Students' daily experiences and interests and choosing laboratory investigations with direct application to everyday life can facilitate the learning of process skills"(Rubin and Tamir, 1988;477). Students interact with materials to observe and understand the natural world. Laboratory activities were used illustrating information presented by the teacher and the textbook on educational and scholarly investigation of the school laboratory was quite limited(Lunetta, $2007 ; 394,395)$

Schoolyard or gardens are important for provide nature-based environments. İndustrialization and urbanization and it's results have deprived children of outdoor and nature-based environments. (Rivken, 1997; 61). We could compare the past and present about this subject. Of course naturel environments were more likely in the past. Many of the school yard with a concrete or asphalt floor and no green space for now. In that case we could say schoolyard is one of the necessities of physical conditions of school. This substance relates to training yields.

Schools museum is other condition that shows a school's physical state. John Dewey -who is a scientist of education- was obtained that there were a connections between school subjects and life activites. School is a living union of thought, this union symbolized by art work, science, history, geography and literary of museum. John Dewy thought that museums should be part of the active learning network of any school. (He1n,2004; 415-419)So we look in our study that, how was this matter in the past?

School museums have been described as a lively class history of Ottoman by Sat1 Bey (Ottoman Educator). Museums provide information about the publication of our national history. The museum display here serve for training of educational materials and textbooks would be possible. While some museums contain all of them, it was to include one or more others. Sat1 Bey has said the museum would be guidelines for schools. Schol museum also argues that teachers and students will increase the enthusiasm and effort.(Taşer, 2011;181)

Some schools have a library also. Students goes to school for learn more information. So library responds to this need. School library is defined as "local arena, a sphere supporting the development of student knowledge, which is reflected in the legislative rules of school. The creation and experience of the school library is embodied by the character of the physical room and by the use of the room according to the ability of the different actors, their desires, thoughts, and engagement". (Limberg, 2003; 5)

The scope of geography education, meteorological information must be given to students. For this some schools might have a meteorology corners. It is known that temperature and pressure measuring devices were in the school in the past. Students gathered in the school yard, and they were examining at this device with teachers. 
Physical facilities in Education is multifaceted. One of them for example is the number of students in a class should be. If the lack of class, is could be improve this ratio. However, when we look at the relevant standards on maximum should be 25-30 students in a class in primary education. On the other hand it is preferred that the single-storey school buildings such as health and economic reasons. The stairs are not that reliable in terms of safety. However, if you need laboratory, library, sports field and conference room and such as units, schools may need to be multi-storey. (Hesapçığlu, 1994; 126,129).

Schools conditions related to size of the settlements. Many states take a prevention to small districts schools. These schools must be strongly encourage to consolidate or to close and replace them with larger, consolidated schools (Howley,2006;2,3)

We have examined small district schools. These schools provides some benefits. For example, fewer students receive more attention and individualized education. Small schools have more safety maybe. Teachers are able to provide more consistent curriculm (Harris,2006; 137). Therefore the physical condition of the school's interest in education yields.

Adaquacy of physical conditions is very important for, the physical conditions of schools should beorganized to increase the motivation of administrators, teachers and students. Researchers can not say that how it should be school size or there isn't any criteria.(Karakütük and others, 2012; 184)

Schools are very important so, we have choose some schools of Anatolia in the past. We have showed physical condition this schools. There was a Ottoman State of Anatolia in $20^{\text {th }}$ century.

The Ottoman State began to establish primary schools -with new procedures- and outside the Madrasa in the early 18th century. Their number of schools has increased considerably in the 19th century. Ottoman Empire opened a primary school in every neighborhood. Quality problems led to the proliferation of schools. Schools are opened numerously outside Istanbul. Ottoman Empire began establishing schools in district or town. But they also need to meet the diverse needs of these schools and, also take information about the general situation of these schools. For this, the ministry of education and training inspectors are assigned to look into this. Investigators did not record the functioning of education alone they recorded the physical condition of schools.

Intensive political events began in the early 20th century. During this period, the First World War took place. While Ottoman State engaged in war, the development of education was of paramount importance, and there was continuous registration of information about the schools during the war. This information is important to recognize the educational opportunities of the past.

\section{Method}

Data were collected at three municipalities in Turkey during the period 1910-1916 and rudely five schools evaluated. We found document from Ottoman Archive. We examine schools that municipalities which Bursa, Malatya and Tokat and thereof districts are Reşadiye and Arapgir. Some of these schools were located urban others rural areas. We have look connection between education yield and physical condition of schools in the past. About the physical conditions of schools are not many studies both nationally and internationally. 
This study wanted to see the school's past with respect to the physical development. To achieve the results of this study, primary documents were reviewed. In a research document about the history of education, it is very important because it is the source of first-hand information. Documents were located in the archive. Therefore, records kept on schools were investigated. The study consists of the assessment in the form of recorded information in the past. This is a qualitative research across the board. Records were read and classified. In this study, data collected, specifically primary data were planned. Research instruments were valid and reliable. All the schools could not be given in the study, some centers in Anatolia were chosen using a random selection; although attention was paid to schools in different locations. For data analysis, information was discussed in a descriptive way.

The study was carried out in the Ottoman Archive of Prime Ministry in Istanbul. There are various classifications in Istanbul. Among them is Educational Department of Board of Inspectors (Maarif Heyet-i Teftişiye Kalemi). In this category, there are tens of files. In each of these files, there are about hundred documents: Department of Board of Inspectors includes the information and documents concerning every stage of education. In this department, the issues about the inspection of supervision of schools took place. The part examined mostly included the primary schools. Also, these documents were utilized in such a way that it would be in the volume of an article.

We have give information about schools past and today with comparative method. Firstly today which subjects are controlling in schools, we can look this.

\section{Finding and Results}

\section{1) Physical structure control of schools and related matters in today}

Today, from the inspection directives prepared by the Headship of Board of Inspectors, it is understood that a number of items about the inspection or supervision of an educational institute should be examined. According to this, the points examined can be put in order as follows:

The points related to the school inspection and physical structure at the presents days Generally, today, the duties and responsibilities of inspectors can be put in order as follows (Ministry of Education, Audit Guide, 2010):

(1) $\mathrm{He} / \mathrm{she}$ gives particular importance guidance. It avoids the approaches and attitudes that words and behaviors will result in the different interpretations as well as the promises and behaviors that offend the teacher and staff.

(2) He/she checks how the legislation and instruction programs are implemented and reports the points he/she identifies during the inspection reports to the head of the group.

(3) As one of the main elements of our national entity, he/she shows the necessary awareness about using Turkish language without de-generating its features and without exaggerating in each stage of education. He/she also makes contribution such that all officials in the institutes should also show their awareness.

(4) During inspections, in case one meets the points that are absent in the legislation, repealed, or open to comment, before opining, after evaluating the matter that cause the hesitation together with the group, he/she makes explanations to whom it may concern. 
(5) $\mathrm{He} / \mathrm{she}$ submits the information including the determinations belonging to the departments he/she inspects to the rapporteur in written way.

(6) $\mathrm{He} / \mathrm{she}$ takes cares of is/her appearance and behaviors.

(7) Generally, duties and responsibilities of inspectors, nowadays can be listed as follows:

\section{The case of problem}

The schools in the different centers of the world nowadays have the technological facilities and favorable physical conditions.

- - Educational settings.

- - Management works.

- - Works of board of teachers.

- - Teaching activities.

- - Education activities.

- - Inspection of teacher.

- - Assessment of manager and psychological counselor.

Here, among the titles examined in inspection, the study sees educational settings as an important part of education. Just as educational settings are related to the physical structure, the subjects examined under this title are given a place as stated (Audit guide for middle school, 2010).

"Training equipments was identified in the form of" whether or not the educational settings are in the qualification to be able to respond to the need will be examined; the deficiencies will be tried to be removed during the duration of inspection; and it will be looked at whether or not the works toward improving the educational settings are handled in the approach of total quality". In this, [thee are] the arrangements related to the garden; keeping the Turkish flag hanged on the flagpole; maintenance and protection of flags; arrangement of Ataturk's bust, and Ataturk's corner; hanging the names of the school, classroom, and department and floor layout plans to the suitable places; taking actions for preventing and extinguishing the fire in the building; the insulation of the electricity systems, water, heating conditioning installation, and similar installations against the outbreak of fire and smoke and having their periodic controls conducted; taking protection actions against earthquake; conformity of location and equipment with the sort of school; subjecting the physical changes made in the building to the approval; providing order, and cleaning with department; carrying out the maintenances of the things and materials; for children of kindergarten, arranging the playing area and garden accordingly for its aim; arranging the archive in accordance with its aim; declassifying and destroying the material that are not needed and that are not required for conserving; forming a school museum in the school, if possible; protecting the health of the students and employees; for the students to be able to go toward research and their being able to use the new technologies; their being able to produce the new information; and use and sufficiency of the classes of information technologies and communication related to this; keeping the workshops, laboratories as well as the visual and audio devices in the private classrooms ready for education; arranging the library in accordance with its aim; making 


\section{lodgment allocations; serving of social facilities in accordance with its aim; and conserving the food substances in accordance with hygiene".}

In 2004, the school inspection manual was changed. This guide was referred for education in the environment, to students, to teachers and for education outcomes, with great success (Audit Guide, 2014). With this, plurality issues examined today which gives room for training activities and better school conditions were not examined in the past. This study look at this substances.

Now in the past which subjects are controlling of schools we can look this.

\section{2) Physical structure control of schools and related matters in past}

In history, the points assessed during the physical inspection of the schools with regard to the report in our educational history can be put in order. The points attracting attention related to the physical states of the schools are:

1. The building of school from the general aspect: how many storey's building it has; the number of classrooms and the other buildings, whether or not they need repairing.

2. Its garden: Whether or not it is enough for the students during break time.

3. The number and quality of the materials such as the desk, table, blackboard, map etc.

4. Whether or not there are school library and museum.

These items were assessed about the physical state and facilities of the school. The study can give place for the implementation samples related to this.

\section{2-1)Applications of inspections of physical conditions}

Ahmet Şerif, the author of the newspaper Tanin, in the years of 1909 to 1910, had been in many centers in Anatolia, and he examined the various institutes and people here. Among the institutes examined by Ahmet Şerif were schools. He mentioned primary, secondary and high schools and university. This information is important in terms of its reflection of the physical state of the schools in history.

For example, Ahmet Şerif, who assesed a primary school in the district Simav, subject to the province of Kütahya, said the roof of this school had collapsed, its walls inclined to different directions individually, and it was airless and with moisture. In the same way, he gave place that in Gilindir, the center of the district Gülnar, the building of school, which had 70 to 80 students, was in the form not to be lived in. Besides the general physical state of the school, he talked about the classrooms as well. In the primary school in the district Beyşehir of the province Konya, it was recognized that 70 to 80 students received education together. This was also qualified as narrow and airless (Şerif, 1999).

Besides these schools, there were some schools, whose physical state was good. And in that time, what was the criterion of "good"? The school whose physical condition was accepted as good? The study can look at this.

A. Şerif, who went to the village İdre, subjects to Taşlica, mentioned the educational state there. He observed that the school building in this village was the best one of the buildings in 
the village. He went to the small room of the teacher. Here it was not completely furnished but was in order. A Şerif, who had come to the school together with the officials assigned by the Educational Ministry, talked about the classroom in this school. This room is not bad for a village school. There were some reading desks and a big blackboard in the classroom. In addition, cleanliness was given importance. The number of the students of the school, which had 3 classrooms, was 14, with 2 females. Normally, in the school, whose number of attendances was 24 , since the season was time of work, 10 children were not continuing the school (Şerif, 1999). Following this overview, the study can look at how the matter regarding the physical adequacies of the school reflected in the reports of inspectors.

Inspectors acted in the direction of duty, which was given to them, and they mention the physical state of the school to the reports they kept about the schools they examine. Issues such as the adequacy of the classrooms in a school, state of course equipment, whether or not the school garden was convenient for the break times, the hygienic state of the school building, and whether or not there were some elements that will form an impediment for education were the important points for education to be carried out healthwise. In order to make the issue tangible, the study can proceed to the points related to the reports kept by the inspectors about the schools in the different centers and sorts.

\section{2-2) Physical state of Bursa Osmangazi school}

The study first example is about Bursa Osmangazi School. After the inspection carried out in this school, the points written in the report of the inspector were:

"The school building has two - floors and three classrooms. There is also a room for a teacher. The bottom floor is a basement and is allocated for fuels etc. The building needs repairing and is not suitable for the school. Since one water closet lying in the bottom floor is not enough for the need of students, it was turned into an unbearable state. First of all, it is better to make some water closets on the well prepared in the corner of school garden. Its garden is enough for break times" (BOA., MF.HTF.5-115, 1336.N.7). As will be understood from these words, there was fuel (wood etc.) in the bottom floor of the two-storey building, which has only two classroom and, since the school building was not suitable for education, it did not seem to be corrected by repair. It was understood that the school building had a lavabo and this was not enough either. It is said that "in terms of educational equipment, there are 20 desks, 5 blackboards, 3 tables, two portraits of padishah, maps were of sufficient amount, 3 stovea, and six flags" (BOA., MF.HTF.5-115, 1336.N.7).

About the library and museum of the school, it is given place the expressions that "There are no libraries and museums. The books for library are recorded in the plant ledger. İt was commended that library notebook should be arranged as in the sample of it; a museum should be made regarding the products of plant and mines". According to this, the school does not have any museum but one is planned to be made (BOA, MF.HTF.5-115, 1336.N.7).

\section{2-3)The physical state of Bursa Murat I application school}

The study can again give another example from Bursa. The evaluations of inspector about Murat I Application School are (BOA., MF.HTF.5-115, 1336.N.7):

"The school building is two -storeys and has 7 rooms, one of which belongs to the headmaster and the other one to janitor. At the bottom part there is a promenade place. The building is wooden and needs repairing. It is not suitable for the school and its garden is 
enough for the needs of the students. On the upper part and the part facing the garden of the building, if a room more is built in the next year, while education begins, the need will be met. As the equipment for learning, there are 45 desks, 9 blackboards, 5 stoves, 3 tables, 1 clock, 2 portraits of padishah, and 8 maps. The desks are made in the old styles but meet the current need. There is a notebook belonging to the financial affairs of the school. The records were regularly kept. There are no library and museums. The books sent by the Ministry were recorded in the existing plant ledger. Commands were given that a library notebook must be put in place, and that a museum must be made, that will display the vegetable and animal products.

It is understood that the number of rooms in this school were more compared to the previous school; that there are separate rooms for the headmaster, teachers, and janitors but that an extra classroom should be made inorder to meet the needs. It is seen that there is no school museum and library.

\section{2-4) The physical conditions in the Reşadiye Inas female school}

The report submitted by the inspector are (BOA., MF.HTF., 5-5): "The school building is a two-storey house, hired. On the first floor, there is a large sofa and 4 rooms, while on the second floor, there are 4 rooms, one of which is a room for janitors. 2 rooms at the bottom floor are used as a dining hall. The school has a considerably large garden. As an institution for learning, there are enough amount of blackboards, schooling board and a piano. The school does not have library and museum. The existing books and magazines are kept in a cupboard. Beginning from the next educational year, building a library, if possible, and establishing a museum were ordered to the chief female teacher".

It is understood that the building of the Reşadiye Female School was hired, it had twostoreys; and consisted of a total of 10 rooms. It is seen that there is also a dining hall in the school. In the part of learning equipment, apart from the other schools, it is remarkable that there was a piano. It is understood that this school did not have any library and museum either.

\section{2-5) Examinations of inspectors in the districts and villages of Malatya}

The reports were, first of all, collected in the educational directorships, and then the educational directors sent these reports to the Educational Ministry. Educational directors were the officers responsible for the educational affairs in the provinces. As earlier explain, just as the inspection reports were prepared in detail and given in summary, in which a general opinion on these reports take place were also reported. In the example regarding this, the expressions "regarding the inspection report by Sanjak Malatya is presented" took place in the content of the letter, beginning with the expressions in the form of Maarif Nezaret-i Celilesi Canib-i Alisine (To Great Educational Ministry). In the letter sent by Elazığ Educational Directorship, contains the following:

The general report, sent by Malatya Primary Education Inspectors, and belonging to the educational year 1331 to 1332 (1915 to1916) has been presented. This report says that "the school in the village Büyükdağ that is subject to the district Kahta, which is absent on the map although it is specified in the report, is opened to be administrated by the administrative supervisor as a consequence of the application of the position province and administrative supervisor". In Malatya, the records kept, related to primary education is: 
"In the central district, Sancak Malatya, there were 9 villages. There were the female and male schools in the center of the district Akçadağ, subject to Malatya and, in 5 villages and 3 towns subject to the district, there were primary schools. In the general evaluation made regarding the inspection carried out in these schools, [It is said that] "the building of most of the schools in this center is not convenient to the sanitary conditions. On the hand, on the reasons for disaster, the building became desolate and is almost collapsed. In addition, the building needs repairing. Besides this, there is a need for teacher. It seems impossible to find a teacher. The existent teachers are not enough in terms of education. The course equipment is missing. Of course, the most important reasons of all these is the advent of the First World War and mobilization order". As it will be understood from here, most of the school buildings are not suitable for education and the most important part of them are in a desolate state due to strong rain. Therefore, they need to be renewed or rebuilt. It was expressed that the course equipment was missing, because the nation is altogether in the world (BOA., MF.HTF, 4-61, 1335.Ra.27).

While the inspectors were telling the activities carried out in the region, to which he was sent to investigate, he also noted the mobility on the date specified. While noting this, he used the expression that "I arrived on the date of Tuesday, May 7, I arrived to the town Arapgir, my investigations and inspections are:" The points the inspector gave place in his report about a school, which he reached on the date of Tuesday, May 7 (BOA., MF.HTF, 4-61, 1335.Ra.27).

School building consists of three sections. One of these three sections was allocated for the student to rest, the other two, to be educated. There is a garden parcel in front of the school. Since the building is new, there is no need for repairing. Thanks to the efforts and aids of chief teacher, the course equipment is perfect and all of them are existent. Furthermore, the accounts are regularly kept related to the financial issuers. Since it has a library but no museum, a warring was made about building a museum.

In this school, it is seen that there was a library that is absent in the other schools. In addition, there are sufficient amount and quality of course equipment. One of the rooms is allocated for the room of a headmaster. It is understood that there is a dining hall in this school and that the garden is enough. The examinations of the inspector here took two days.

The information belonging to the inspection and examinations of the inspector, who went to the school of the neighborhood Ulupinar of Arabkir on the date of Wednesday, May 8 is as follows (BOA., MF.HTF, 4-61, 1335.Ra.27):

School building consists of three classrooms, one of which is large, the other two small. Just as there is no need for repairing this school, it does not have any garden. The place for break time is large. The course equipment is missing. The processes related to the account are not regularly recorded. Library and Museums was absent.

It is understood that the course equipment of the school, whose break time place is large, is missing. Inspector arrived at the Arapgir town of Eskişehir on the date of Thursday May, 9. His examinations and inspections were given place below (BOA., MF.HTF, 4-61, 1335.Ra.27):

School building included four classroom, one corridor, and one room for teachers which was built in 1914, but since mobilization interrupted it, the construction of building could not 
be completed. However, the part which cannot be completed did not comprise any barrier for carrying out the education. A large part of it is not existent. However, the efforts are exerted for completing. The financial income -expenditure notebook of the school were not completed as it should be.

Therefore, a sample page was given and it was expected to be completed accordingly. There was no library and museum. It is understood that the building, whose construction begun in 1914, could not be completed due to the beginning of First World War. But since there is nothing impeding the education, the students continued the courses. In the school, it is understood that there is no course equipment, it is stated that there are some attempts to supply them.

When we saw these information, we could reach generally table, about schools conditions in the past. We can create a statistics.

Table 1- Statistics About School Condition For Four School İn The Past (In The Early $20^{\text {th }}$

\begin{tabular}{|c|c|c|c|c|}
\hline \multicolumn{5}{|c|}{ Century) } \\
\hline Conditions & $\begin{array}{l}\text { Bursa } \\
\text { Osmangazi } \\
\text { School }\end{array}$ & $\begin{array}{l}\text { Bursa Murat I } \\
\text { application } \\
\text { school }\end{array}$ & $\begin{array}{l}\text { Reşadiye İnas } \\
\text { female school }\end{array}$ & $\begin{array}{l}\text { Malatya Arapgir } \\
\text { School }\end{array}$ \\
\hline Floor & 2 & 2 & 2 & 2 \\
\hline Classes & 3 & 5 & 8 & 3 \\
\hline $\begin{array}{l}\text { Teacher } \\
\text { room }\end{array}$ & $\checkmark$ & $\checkmark$ & - & - \\
\hline $\begin{array}{l}\text { School } \\
\text { Principal } \\
\text { Room }\end{array}$ & - & $\checkmark$ & - & - \\
\hline Cellar & $\checkmark$ & & & - \\
\hline Janitor room & & - & $\checkmark$ & - \\
\hline $\begin{array}{l}\text { Break place } \\
\text { Library }\end{array}$ & $\begin{array}{l}\text { Enough size } \\
\text { - }\end{array}$ & $\begin{array}{l}\text { Enough size } \\
\text { - }\end{array}$ & $\begin{array}{l}\text { Enough size } \\
\text { - }\end{array}$ & $\underset{\checkmark}{\text { Enough size }}$ \\
\hline Museum & 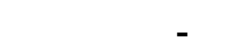 & - & - & - \\
\hline Lavatory & Enough & Enough & Enough & Enough \\
\hline $\begin{array}{ll}\text { Need } & \text { a } \\
\text { repair }\end{array}$ & Yes & Yes & Yes & $\begin{array}{l}\text { No(Because } \\
\text { new) }\end{array}$ \\
\hline
\end{tabular}

This table show that four different school in Anatolia in the past. When we saw this table, we can get a general idea about schools in history. This schools located upstate or countryside. So that many schools not have a museum or library. Genarally schools were two floor and have a wide garden and break place.

\section{Discussion and Suggestion}

The situation of educational institutions in the history may be questioned. How did the physical structure of the school look? How many classes does the school have? What were the lesson tools, teaching and learning process? How does the school administrator prepared the school's financial matters? Is there a school museum and library? These questions show that schools and education administration is related to these subjects in the history. It is argued today, that there are more bodies intensively addressing these subject issues.

Normally, resources related to the physical structure of the school are not enough for Ottoman 
State. To this effect, some information can be found in the inspection book. When we look at the findings were not regularly physical condition of the schools in history because war. Today it is also debatable that, which units should be in schools strictly. For example, this question was asked in the past that, whether the school has a museum or library? Inspectors recorded these conditions in the past. In that case, these can be discussed, if financial resources were adequate in the past, there could have been more qualified physical structure of the schools.

Having a standard for the physical facilities of the school may be useful. For example, a school may have physical facilities in extremely good conditions. In another school, these facilities are inadequate. So they cannot compete in the same conditions in the two school children.

In a period, when there are some inadequacies from economic point of view, the educational possibilities were assessed. According to this, while some equipment was seen inadequate, the missing ones in some of the schools were emphasized. Despite all impossibilities, it is important that there is a piano in a female secondary school. In the study, the educational institutes in the different centers of Ottoman State were given in place. These educational institutes are in the primary and secondary degree and those belonging to the males and females were separately evaluated.

Nowadays, studies under a number of subject matter regarding the educational setting during the inspection of school are carried out. Also in the past, the records were kept about the physical constructions and facilities of the schools in the scope of school inspection. But the titles examined in the past are more limited. However, in the early 20th century, there is important information about the physical states and facilities of the schools in Anatolia. This information enables us to better understand the period and educational facilities. Most of the school buildings were hired where the educational activities were carried out. On the other hand, the equipment that is available in the setting of classroom can be put in order as table, chair, portrait of padishah, flag, and map

During the inspection of school, the control of the school museum and library as well as financial points regarding school actualized, especially giving importance to museum indicated that the use of three-dimensional materials was given attention.

\section{References}

Prime Minister Ottoman Archive (BOA) Documents:

BOA., MF.HTF.5-115, 1336.N.7.

BOA., MF.HTF., 5-5.

BOA., MF.HTF, 4-61, 1335.Ra.27.

\section{Other Resources}

Chairman Of The Supervisory Board, Provincial And District Directorates Of National Education Audit Guide (2010). Ministry of Education, Ankara. Guidance And Supervision Presidency

Başar, Mustafa Aydın, (2000), Staff and Physical Possibilities of Primary Schools, The Journal of PAÜ Education Faculty, Volume:8, pp.134-140. 
Creemers, B. P., \& Reezigt, G. J. (1999). The role of school and classroom climate in elementary school learning environments. School climate: Measuring, improving and sustaining healthy learning environments, 30-47.

Elementary And Secondary Schools Guidance And Supervision Guide (2014). Ministry of Education, Ankara.

Fraser, B. J. (2012). Classroom environment (Vol. 234). Routledge.

Hein, G. E. (2004). John Dewey and museum education. Curator, 47(4), 413-427.

Harris, D. N. (2006). Class size and school size: Taking the trade-offs seriously. Brookings papers on education policy, 2006(1), 137-161.

Hesapçığlu Muhsin, Meriç Beyhan(1994), "The Design Of The School Building, Training Facilities in İstanbul and Turkey, Preliminary Analysis for Population, Education And The Economy" The Journal of Education Science of M.Ü. Atatürk Educatıon Faculty, Volume:6, pp.123-148.

Howley, A., \& Howley, C. (2006). Small schools and the pressure to consolidate. education policy analysis archives, 14(10), 1-31.

Lunetta, V. N., Hofstein, A., \& Clough, M. P. (2007). Learning and teaching in the school science laboratory: An analysis of research, theory, and practice.Handbook of research on science education, 393-441.

Karakütük and others, (2012) "The Adequacy of Physical Conditions of Public High Schools in Turkey According To Their Sizes", Ankara University, Journal of Faculty of Educational Sciences, vol.45, no:2, 183-204

Limberg, L., \& Alexandersson, M. (2003). The school library as a space for learning. School Libraries Worldwide, 9, 1-15.

Middle School Audit Guide (2010). Ministry ofEducation, Ankara.

Rivkin, M. (1997). The schoolyard habitat movement: What it is and why children need it. Early Childhood Education Journal, 25(1), 61-66.

Rubin, A., \& Tamir, P. (1988). Meaningful learning in the school laboratory. The American Biology Teacher, 477-482.

Şerif Ahmet, (1999),Turkish Historical Society , Tanin (Newspaper) of Anatolia, Translated, Mehmet Çetin Börekçi, Volume I, Ankara.

Şerif, Ahmet, (1999) Turkish Historical Society, Tanin (Newspaper) of Albania, Syria, Tripoli, Translated, Mehmet Çetin Börekçi, Volume II, Ankara.

Taşer, Seyit, (2011), The Last Period Of The Ottoman İntellectuals Views On Educational İssues, Education Publishing, Konya.

mebk12.meb.gov.tr/meb_iys_dosyalar/46/02/.../24084611_okul.ppt 